Article

\title{
Cytotoxicity, Genotoxicity and Disturbance of Cell Cycle in HepG2 Cells Exposed to OTA and BEA: Single and Combined Actions
}

\author{
Ana Juan-García ${ }^{1, * \mathbb{D}}$, Josefa Tolosa ${ }^{1,2}{ }$, Cristina Juan ${ }^{1}$ and María-José Ruiz ${ }^{1}$ (D) \\ 1 Laboratory of Food Chemistry and Toxicology, Faculty of Pharmacy, University of Valencia, Av. Vicent \\ Andrés Estellés s/n, Burjassot, 46100 València, Spain; josefa.tolosa@uv.es (J.T.); cristina.juan@uv.es (C.J.); \\ m.jose.ruiz@uv.es (M.-J.R.) \\ 2 ProtoQSAR, CEEI, Avda. Benjamin Franklin 12, Paterna, 46980 Valencia, Spain \\ * Correspondence: ana.juan@uv.es
}

Received: 21 March 2019; Accepted: 13 June 2019; Published: 14 June 2019

check for updates

\begin{abstract}
Mycotoxins are produced by a number of fungal genera spp., for example, Aspergillus, Penicillium, Alternaria, Fusarium, and Claviceps. Beauvericin (BEA) and Ochratoxin A (OTA) are present in various cereal crops and processed grains. This goal of this study was to determine their combination effect in HepG2 cells, presented for the first time. In this study, the type of interaction among BEA and OTA through an isobologram method, cell cycle disturbance by flow cytometry, and genotoxic potential by in vitro micronucleus (MN) assay following the TG 487 (OECD, 2016) of BEA and OTA individually and combined in HepG2 cells are presented. Cytotoxic concentration ranges studied by the MTT assay over 24,48 , and $72 \mathrm{~h}$ were from 0 to $25 \mu \mathrm{M}$ for BEA and from 0 to $100 \mu \mathrm{M}$ for OTA, while BEA + OTA combinations were at a 1:10 ratio from 3.4 to $27.5 \mu \mathrm{M}$. The toxicity observed for BEA was higher than for OTA at all times assayed; additive and synergistic effects were detected for their mixtures. Cell cycle arrest in the G0/G1 phase was detected for OTA and BEA + OTA treatments in HepG2 cells. Genotoxicity revealed significant effects for BEA, OTA, and in combinations underlining the importance of studying real exposure scenarios of chronic exposure to mycotoxins.
\end{abstract}

Keywords: ochratoxin A; beauvericin; mixtures; HepG2 cells; genotoxicity; cell cycle

Key Contribution: Single mycotoxins OTA and BEA and their mixtures produce cytotoxicity, genotoxicity, and cell cycle disturbance in HepG2 cells.

\section{Introduction}

The presence of mycotoxins in food and feed have associated toxicological effects in consumers such as nephrotoxicity, hepatotoxicity, teratogenicity, etc., or potential effects such as synergism, additive or antagonism when a combination of more than one mycotoxin occurs [1-5]. The overall evidence on mixture effects indicates that combined effects can arise when each mixture component is present at doses around or above its no-effect level and provides a strong basis for developing robust approaches to assess the risk of chemical mixtures to support decision making [6].

Studies of mixtures of mycotoxins are directed to find whether there is an interaction between them, and if so, whether this interaction potentiates or diminishes the toxic effects of mycotoxins tested individually. When there is no interaction of mycotoxins between them, their effect is described as additive; while if the combination increases or decreases, the effect expected is described as a synergistic or antagonistic interaction, respectively. For this purpose, several models can be used to study such interactions. The mathematical model "Loewe Additivity" uses the isobologram equation proposed 
by Chou and Talalay et al. [7,8], which involves plotting the dose-effect curves (defined to a certain inhibition level) for each compound and their combinations in multiple diluted concentrations as described elsewhere [1-3,9].

The presence and co-presence of more than one mycotoxin in food and feed due to the ability of most Fusarium to simultaneously produce different mycotoxins is very common; thus, exposure to multi-mycotoxins often occurs [10-12]. Mixtures found worldwide have started to increase and become more diverse over the last decade due to the climatic changes and favorable growth conditions of different fungi spp. [12].

The EFSA has recently published a Draft Guidance document where a harmonized risk assessment methodology for combined exposure to multiple chemicals for all relevant areas is described (EFSA Journal 2018). There are specific requirements for chemical mixture risk assessment on the use of pesticides and food and feed additives [13,14], while for some mycotoxins, the sum of T-2 and HT-2 and the sum of aflatoxin B1 (AFB1), aflatoxin B2 (AFB2), aflatoxin G1 (AFG1), and aflatoxin G2 (AFG2) are underpinned in Regulation (EC) 1881/2006 [15]; however, neither beauvericin (BEA) nor ochratoxin A (OTA) are included.

For detecting genotoxicity, micronuclei (MN) induction assay has been accepted, validated, and recently updated in the Test Guideline 487 (TG 487) by the OECD [16]; and the inclusion of flow cytometry in the new TG 487 is a novelty which allows to determine cell cycle effect and MN-induction simultaneously $[17,18]$. Most of the articles published perform in vitro detection of MN through cytokinesis-block micronucleus (CBMN) assay for genotoxicity studies of mycotoxins produced by different fungal genera (Fusarium, Penicillium, and Aspergillus). Studies for Ochratoxin A (OTA), citrinin (CTN), patulin (PAT), beauvericin (BEA) [19-26], and aflatoxin B1 (AFB1) [27] can be found.

The new findings from cytotoxicity induced by binary mixtures of BEA + OTA in PK-15 cells and human leukocytes reveal that combined toxicity is higher than predicted from individuals; in fact, synergism and additive effects have been reported [28].

The in vitro system HepG2 cells are commonly used in toxicological studies. Effects reported for BEA, OTA, and its combination are diverse and it depends on different factors such as intake dose, exposure frequency, and timing of functional assays; in fact, their combination effect in HepG2 cells is here presented for the first time. In this study, the type of interaction between BEA and OTA through an isobologram method was studied. It is also presented the results of studying cell cycle disturbance by flow cytometry and genotoxic potential by in vitro micronucleus (MN) assay following the TG 487 [16] for BEA and OTA individually and in different mixtures in HepG2 cells.

\section{Results}

\subsection{Cytotoxicity of Individual and Combined Mycotoxins}

Ceauvericin and OTA mycotoxins and their combination on HepG2 cells during 24, 48, and $72 \mathrm{~h}$ were studied through the MTT assay to evaluate the cytotoxicity. The assay was driven to determine the $\mathrm{IC}_{50}$ (inhibition of cell population to $50 \%$ ) value. The $\mathrm{IC}_{50}$ values denoted that BEA was above OTA (BEA > OTA) in toxicity potential when individual treatment was evaluated (Figure 1a,b and Table 1); however, a dose-dependent manner (Figure 1c) of toxicity in $\mathrm{IC}_{50}$ values was achieved for mixtures of both mycotoxins. The highest toxic effect belonged to BEA at $72 \mathrm{~h}$ expressed by an $\mathrm{IC}_{50}$ level of $5.5 \pm 0.071 \mu \mathrm{M}$. The $\mathrm{IC}_{50}$ values for each mycotoxin at different times of exposure are shown in Table 1.

For the BEA represented in Figure $1 \mathrm{a}$, a concentration range of 2.5 to $25 \mu \mathrm{M}$ viability values decreased in a time-dependent manner. At $24 \mathrm{~h}$, reduction of viability was from 54 to $43 \%$, whereas the reduction of viability was from 60 to $82 \%$ and from 90 to $73 \%$ for $48 \mathrm{~h}$ and $72 \mathrm{~h}$, respectively. Figure $1 \mathrm{~b}$ shows the concentration-dependent decrease of viability of HepG2 cells after OTA treatment. It produced a reduction of viability from 70 to $30 \%$ and from 65 to $47 \%$ at 24 and 48 h, respectively, whereas the reduction of viability for $72 \mathrm{~h}$ varied from 93 to $82 \%$. 
a)

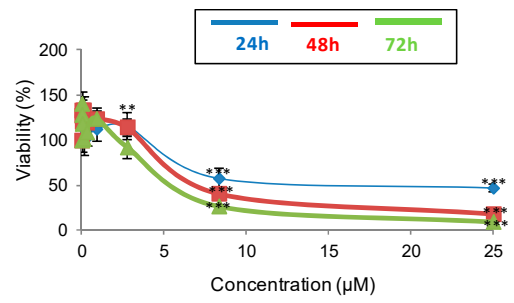

b)

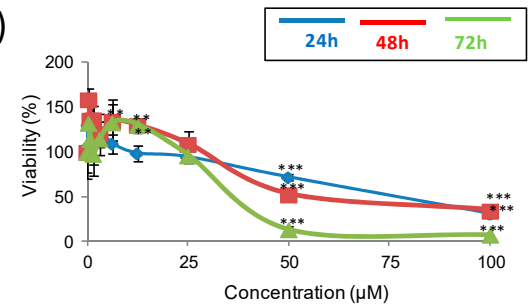

c)
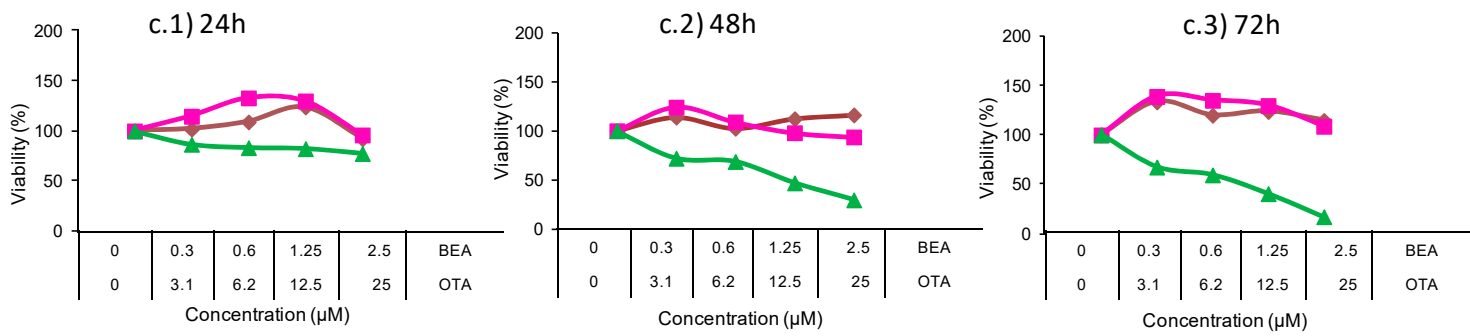

OTA: line and square BEA: line and diamond; Mixture: line and triangle

Figure 1. Cytotoxicity of BEA (a), OTA (b), and BEA + OTA (c) on HepG2 cells at mycotoxin exposures of 24,48 , and $72 \mathrm{~h}$. The concentration for OTA mycotoxin was 0-100 $\mu \mathrm{M}$ (1:2 dilution), for BEA 0-25 $\mu \mathrm{M}$ (1:3 dilution), while for BEA + OTA at 1:10 ratio. ${ }^{*} p \leq 0.05$.

Table 1. The medium inhibitory concentration $\left(\mathrm{IC}_{50}\right)$ of beauvericin (BEA) and Ochratoxin $\mathrm{A}(\mathrm{OTA})$ in HepG2 cells after 24,48 , and 72 h of exposure by MTT assay.

\begin{tabular}{cccc}
\hline \multirow{2}{*}{ Mycotoxins } & \multicolumn{3}{c}{ IC $_{\mathbf{5 0}}(\boldsymbol{\mu M})$} \\
\cline { 2 - 4 } & $\mathbf{2 4} \mathbf{~ h}$ & $\mathbf{4 8} \mathbf{~ h}$ & $\mathbf{7 2} \mathbf{~ h}$ \\
\hline OTA & $75 \pm 0.04$ & $52.62 \pm 0.06$ & $36 \pm 0.09$ \\
BEA & $12.5 \pm 0.04$ & $7.01 \pm 0.05$ & $5.5 \pm 0.07$ \\
\hline
\end{tabular}

Figure 1c shows the concentration-dependent decrease in the HepG2 cell viability with combined treatment of BEA + OTA (1:10) at exposure times of 24,48 , and $72 \mathrm{~h}$. The $\mathrm{IC}_{50}$ values were obtained for 24 and $48 \mathrm{~h}$ comprised in a concentration mixture range of BEA + OTA from $0.6+6.2$ to $1.25+12.5 \mu \mathrm{M}$ for both exposure times. The reduction of viability caused by the mycotoxin combination BEA + OTA (1:10) was different according to the exposure time: (i) at $24 \mathrm{~h}$ it oscillated between $6-49 \%$ and $3-26 \%$ for BEA and OTA, respectively, compared to the individual mycotoxin exposure; (ii) at $48 \mathrm{~h}$, the reduction oscillated between $25-84 \%$ and $40-78 \%$ for BEA and OTA, respectively, compared to the individual mycotoxin exposure. Finally, at $72 \mathrm{~h}$, reduction of viability oscillated between $19-77 \%$ and $31-83 \%$ for BEA and OTA, respectively, compared to the individual mycotoxin exposure.

The isobologram analysis was used to determine the type of interaction between BEA and OTA. The parameters $D m, m$, and $r$ of the binary and tertiary combinations, as well as mean combination index $(\mathrm{CI})$ values are shown in Table 2. The CI versus fractional effect $(f a)$ curves for BEA and OTA combinations in HepG2 cells are shown in Figure 2. Both Table 2 and Figure 2 demonstrated that the main effect caused by binary mixtures of BEA and OTA is synergism; however, for BEA + OTA mixture at $24 \mathrm{~h}$, additive effect was observed as well as at $48 \mathrm{~h}$ for the highest $\mathrm{CI}$ evaluated (Figure 2 and Table 2). 
Table 2. The parameters $D m, m$, and $r$ are the antilog of $x$-intercept, the slope, and the linear correlation of the median-effect plot, which signifies the shape of the dose-effect curve, the potency $\left(\mathrm{IC}_{50}\right)$, and the conformity of the data to the mass action law, respectively [7,8]. Dm and $m$ values are used for calculating the CI value (CI $<1,=1$ and $>1$ indicates synergism (Syn), additive (Add), and antagonism (Ant) effects, respectively. $\mathrm{IC}_{25}, \mathrm{IC}_{50}, \mathrm{IC}_{75}$, and $\mathrm{IC}_{90}$ are the doses required to inhibit proliferation at 25, 50, 75, and 90\%, respectively. CalcuSyn Software provide automatically these values.

\begin{tabular}{|c|c|c|c|c|c|c|c|c|c|c|c|c|}
\hline \multirow{2}{*}{ Mycotoxin } & \multirow{2}{*}{ Time (h) } & \multirow{2}{*}{$D m(\mu \mathrm{M})$} & \multirow{2}{*}{$m$} & \multirow{2}{*}{$r$} & \multicolumn{8}{|c|}{ CI Values } \\
\hline & & & & & \multicolumn{2}{|c|}{$\mathrm{CI}_{25}$} & \multicolumn{2}{|c|}{$\mathrm{CI}_{50}$} & \multicolumn{2}{|c|}{$\mathrm{CI}_{75}$} & \multicolumn{2}{|c|}{$\mathrm{CI}_{90}$} \\
\hline \multirow{3}{*}{ BEA } & 24 & 19.12 & 2.51 & 0.907 & & & & & & & & \\
\hline & 48 & 13.13 & 2.94 & 0.920 & & & & & & & & \\
\hline & 72 & 8.19 & 2.37 & 0.967 & & & & & & & & \\
\hline \multirow[t]{3}{*}{ OTA } & 24 & 86.73 & 2.02 & 0.960 & & & & & & & & \\
\hline & 48 & 77.57 & 4.24 & 0.915 & & & & & & & & \\
\hline & 72 & 46.64 & 4.01 & 0.956 & & & & & & & & \\
\hline \multirow[t]{3}{*}{ BEA + OTA } & 24 & 6.95 & 2.15 & 0.636 & $1.17 \pm 2.48$ & Add & $1.17 \pm 3.8$ & Add & $1.17 \pm 5.8$ & Add & $1.17 \pm 8.9$ & Add \\
\hline & 48 & 1.79 & 1.86 & 0.948 & $0.27 \pm 0.08$ & Syn & $0.37 \pm 0.14$ & Syn & $0.49 \pm 0.24$ & Syn & $0.65 \pm 0.42$ & Add \\
\hline & 72 & 0.95 & 1.57 & 0.987 & $0.22 \pm 0.04$ & Syn & $0.32 \pm 0.06$ & Syn & $0.46 \pm 0.10$ & Syn & $0.66 \pm 0.19$ & Syn \\
\hline
\end{tabular}


A)

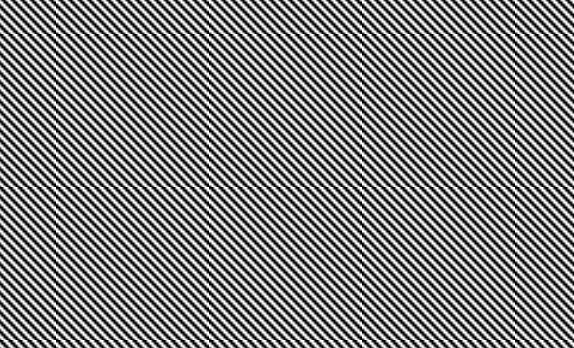

B)

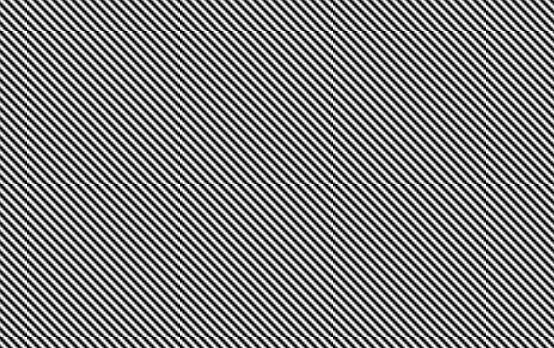

C)

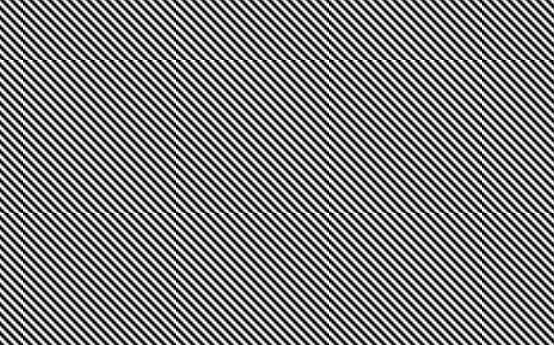

Figure 2. Combination index (CI) versus fractional effect curve as described by Chou and Talalay [7] model on HepG2 cells exposed to BEA + OTA (1:10) in binary combination. Each point represents the $\mathrm{CI} \pm \mathrm{SD}$ at a fractional effect as determined in our experiments. The line $(\mathrm{CI}=1)$ indicates additivity, the area under this line synergism, and the area above the line antagonism. HepG2 cells were exposed during 24 (A), 48 (B), and $72 \mathrm{~h}(\mathrm{C})$ to BEA + OTA at a molar ratio of 1:10 (equimolar proportion).

\subsection{Cell Cycle Distribution in Individual Mycotoxin Exposure}

Analysis of DNA content by flow cytometry provides a measure of cell cycle perturbation in HepG2 cells following exposure to BEA, OTA, and BEA + OTA (Figure 3).

A) BEA 70

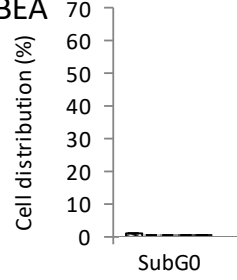

B) OTA

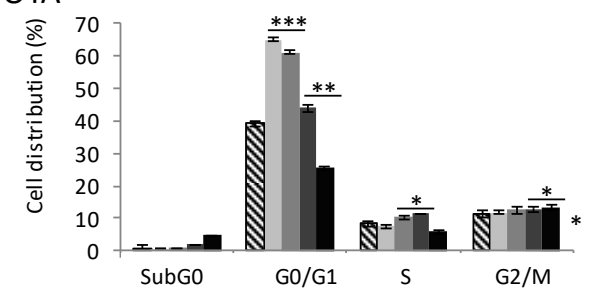

C) $B E A+O T A$

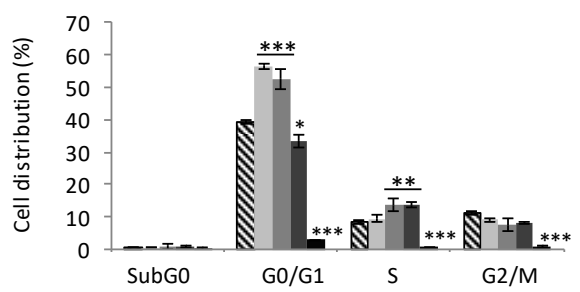

$\triangle$ Control

$=0.31 \mu \mathrm{M}$

$=0.62 \mu \mathrm{M}$

- $1.25 \mu \mathrm{M}$

- $2.5 \mu \mathrm{M}$ \begin{tabular}{|} 
\$ Control \\
$3.1 \mu \mathrm{M}$ \\
$\square .2 \mu \mathrm{M}$ \\
$\square 12.5 \mu \mathrm{M}$ \\
$\square 25 \mu \mathrm{M}$
\end{tabular}

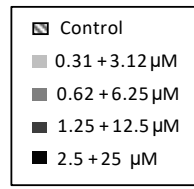

Figure 3. Cell cycle distribution in HepG2 cells exposed after $48 \mathrm{~h}$ to BEA (A), OTA (B), and BEA + OTA (1:10 molar proportion) (C). Data are expressed as mean $\pm \operatorname{SEM}(n=3) .{ }^{*} p \leq 0.05,{ }^{* *} p \leq 0.01$, and *** $p \leq 0.001$ indicates significant differences compared to control. 
Results for BEA exposure to all concentrations assayed resulted in statistically significant differences with respect to the control for all phases: G0/G1 ( $p \leq 0.001), \mathrm{S}(p \leq 0.01)$, and G2/M $(p \leq 0.05)$ (Figure 3A). Effects observed correspond to a statistically significant decrease in the percentage of the number of cells compared to the control. For OTA exposure to all concentrations assayed, the results were a statistically significant increase with respect to the control for the G0/G1 phase ( $p \leq 0.001$ and $p \leq 0.01$ for both higher and lower concentrations, respectively) (Figure 3B). Similarly, this happened for the $\mathrm{S}$ and G2/M phases for doses of 6.2 and $12.5 \mu \mathrm{M}$ (S phase), and 12.5 and $25 \mu \mathrm{M}$ (G2/M phase). The sub-G0 phase reported an increase of HepG2 cells at the highest concentration assayed $(25 \mu \mathrm{M}, p \leq 0.01)$.

Regarding binary mixture BEA + OTA, a statistically significant increase was observed for the G0/G1 phase at concentrations of $0.31+3.12$ and $0.62+6.25 \mu \mathrm{M}$ and in the $\mathrm{S}$ phase for $1.25+12.5$ and $2.5+25 \mu \mathrm{M}$ compared to the control (Figure $3 \mathrm{C}$ ).

\subsection{Micronuclei Induction in Individual and Combined Mycotoxin Exposure}

Figure 4 collects MN frequencies in HepG2 cells exposed to BEA, OTA, and BEA + OTA. Among all two individual treatments, the increase effect on $\mathrm{MN}$ frequency was detected for BEA at a concentration of $1.25 \mu \mathrm{M}(14.2 \pm 1.1 \%, p \leq 0.01)$. OTA revealed decreasing differences in respect to the no-treatment control for all concentrations except at $25 \mu \mathrm{M}$ where statistically significant increases were detected $(p \leq 0.05)$. Regarding BEA + OTA combined treatments, increases in MN frequency at the lowest concentrations assayed were detected as follows: $28.3 \pm 1.32 \%$ and $24.0 \pm 0.97 \%$ for $0.31+3.12$ and $0.62+6.25 \mu \mathrm{M}(p \leq 0.01)$, respectively.

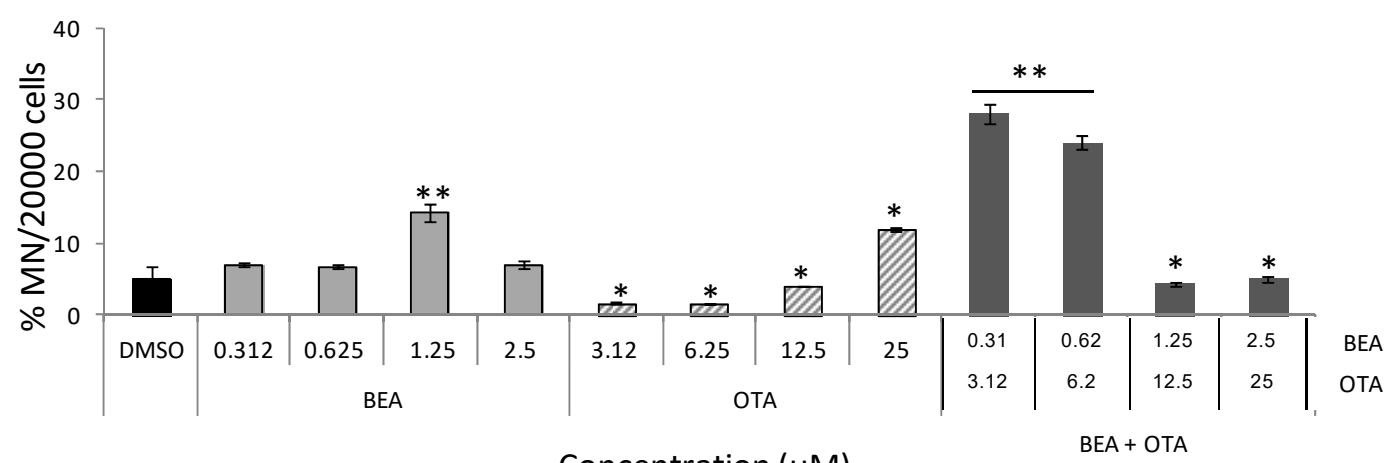

Figure 4. Induction of micronuclei in HepG2 cells treated by BEA, OTA, and BEA + OTA at several concentrations for $48 \mathrm{~h}$. Results are expressed as a percentage of MN per 20,000 cells \pm SEM $(n=3)$. $p \leq$ $0.05\left(^{*}\right)$ and $p \leq 0.001\left({ }^{*}\right)$, significantly different from the control.

\section{Discussion}

Cytotoxicity of BEA and OTA in HepG2 cells either in single or combined treatment was detected; subsequently, cell cycle alterations and micronuclei induction either individually or combined were assayed.

Among both mycotoxins, literature of OTA is wider than that compared to BEA; therefore, several studies performed in in vitro or in vivo models can be found. OTA has been classified as group 2B by the International Agency of Research in Cancer (IARC) and appears in the regulation EC No 1881/2006 [15] and recommendations [29] by the EC in respect to maximum levels in food and feed; in contrast, BEA is not classified as a carcinogen to humans and is not included in the Commission Regulation (EC) No 1881/2006 [15], which established maximum levels for specific contaminants to protect public health. However, efforts are focused in this mycotoxin, since in 2018 the EFSA published a Scientific Report related to in vivo toxicity and genotoxicity of BEA based on the fact that there are insufficient data to establish its reference values.

Regarding cytotoxicity, several authors studied OTA $(0-200 \mu \mathrm{M}$ at 4-24 h) in primary rat PT and LLC-PK1 cells [30], and $\mathrm{IC}_{50}$ values were of 1.1-fold higher and 0.3-fold lower, respectively, to 
each cell line compared to those obtained for HepG2 cells at $24 \mathrm{~h}$ in this study. In BME-UV1 and MDCK cells, OTA IC 50 values were 0.8 and $1 \mu \mathrm{g} / \mathrm{mL}$, respectively, showing a high sensitivity in this cell type compared with other cell models [31]. The HepG2 cells exposed to OTA (10-50 $\mu \mathrm{M})$ reached an $\mathrm{IC}_{50}$ value 0.6 -fold lower than that obtained in this study for the same period of time $(24 \mathrm{~h})$. This can be related with the type of cells used; in this study, HepG2 were used, which are characterized by containing high enzymatic activity. Several studies have revealed alterations in different enzyme activities after OTA exposure, indicating such effect as a potential target for OTA mycotoxin [32].

On the other hand, cytotoxic studies of BEA can also be found. CCRF-CEM cells exposed to BEA $(1-10 \mu \mathrm{M})$ for $24 \mathrm{~h}$ [33] revealed an $\mathrm{IC}_{50}$ value 9.8-fold smaller than that of the HepG2 cells in this study. In HT-29 cells, $\mathrm{IC}_{50}$ values were closer to those reported here differing 0.8 - and 0.7-fold lower for 24 and $48 \mathrm{~h}$, respectively; while for Caco-2 cells, it was 0.6- and 0.5-fold lower for 24 and $48 \mathrm{~h}$, respectively [34,35]. In general terms, comparing data from the literature with the results of this work, BEA IC ${ }_{50}$ values of HepG2 cells were smaller than those obtained with other cell lines; however, for the cell line $\mathrm{CHO}-\mathrm{K} 1$, higher cytotoxicity was revealed since $\mathrm{IC}_{50}$ values were lower than those obtained in this study (1.2- and 3.18-fold lower for 24 and $72 \mathrm{~h}$, respectively) [36]. An explanation for HepG2 sensitivity might be related to the high enzyme activity of these cells and the possibility that BEA exerts cytotoxicity associated to its hexadepsipeptide structure which is able to affect DNA migration, intracellular calcium levels, and apoptosis, as reported [28].

A study on PK-15 cells at fixed doses of BEA and OTA revealed decreases in viability for BEA at $35 \%(5 \mu \mathrm{g} / \mathrm{mL}, 24 \mathrm{~h})$ and $26 \%(0.5 \mu \mathrm{g} / \mathrm{mL}, 48 \mathrm{~h})$; while for OTA at $32 \%(5 \mu \mathrm{g} / \mathrm{mL}, 24 \mathrm{~h})$ and $23 \%$ $(0.5 \mu \mathrm{g} / \mathrm{mL}, 48 \mathrm{~h})$ but no $\mathrm{IC}_{50}$ values were reached for any mycotoxin [37]. However, human leukocytes exposed to BEA, OTA, and BEA + OTA after $24 \mathrm{~h}$, reached $\mathrm{IC}_{50}$ values 2.5- and 4.74-fold lower for BEA and OTA, respectively, compared to those for HepG2 cells reported in this study [28], which coincides with our results of OTA being less toxic than BEA. When studying BEA + OTA (at a 1:10 ratio) (24 h) additive and synergism effects were observed in PK-15 cells [28]; at short times (24 h) in our study, only the additive effect was observed (see Table 2 and Figure 2). Differences in such combination effects could be associated to cell type but also to the concentration assayed. Klaric et al. [28] assayed from 3- to 5-times lower than the concentration of BEA and OTA, respectively, when combined, compared to the ones presented here where the effect was measured with the isobologram analysis, while Klaric et al. [28] reported effects comparing prediction between expected and measured values.

Cytotoxicity observed in HepG2 cells after exposure to mycotoxins BEA and OTA can interfere in cell proliferation; so, the study of phases in cell cycle distribution (Figure 3) and its association with MN induction were studied (Figure 4). In general terms, cell cycle accumulation in the G0/G1 phase was detected for OTA (all concentrations except at $25 \mu \mathrm{M}$ ) and its combination with BEA (at the lowest concentrations assayed), while for BEA a decrease in G0/G1 was detected, revealing induction of cell death at the concentrations assayed. The HepG2 cells need $48 \mathrm{~h}$ to occur 1.5-2 times more than the normal cell cycle division, which is the condition needed to perform the MN assay according to OCDE TG 487. Cell cycle and MN assays were performed in the same conditions to associate alterations in cell cycle and MN induction as described by Juan-García et al. [18]. Among that, although there are few studies carried out in evaluating genotoxicity for BEA and OTA, to our knowledge, this is the first report on BEA, OTA, and BEA + OTA genotoxicity determined by flow cytometry, as approved in the reviewed version of OCDE TG 487 from July 2016.

Results for BEA in the cell cycle disturbed the distribution of phases compared to the control as described in Section 2.2; however, BEA $1.25 \mu \mathrm{M}$ reported differences in all cell cycle phases in respect to the control (Figure $3 \mathrm{~A}$ ) and the strongest $\mathrm{MN}$ induction (Figure 4). Positive results have been reported for genotoxicity of BEA through cytokinesis-block micronucleus (CBMN) assay [26] and the COMET assay [28] as well as negatives [38]. Our results coincide with those positives which for all concentrations BEA MN-induction (here through flow cytometry) in HepG2 cells was observed but it was only statistically significant at $1.25 \mu \mathrm{M}$. 
For OTA, a marked arrest in the G0/G1 phase at the lowest concentration assayed was detected (Figure 3B), which reveals that the HepG2 cells had everything in the cells ready for DNA synthesis but no DNA division happened. This point is associated with the fact that no increase in MN induction was detected unless OTA-high doses were tested (Figure 4), coinciding with other authors [20]. Other authors have compared genotoxic assays (COMET and CBMN) in HepG2 cells exposed to OTA revealing formation of $\mathrm{MN}$ and associating this at least partly to clastogenic effects; although no additional assay to contrast the results were performed [19]. In the present study, MN formation was measured simultaneously with cell cycle and the results were linked (Figures 3 and 4). Previously, we performed this procedure for DON, 3-ADON and 15-ADON in the same cell line, and arrest in the G0/G1 phase was associated with MN induction and the procedure followed was the same as here (OECD TG487 reviewed in 2016 for cytoplasma MN detection in interphase cells) [18]. Several cell models, experimental conditions, and procedures have been used to study OTA-MN induction [21,39]. A recent study has been published using in Vero cells where OTA $(25 \mu \mathrm{M}, 30 \mathrm{~min})$ produced a significant increase in the MN total number through CBMN assay [20]. It is important to mention that OTA is known as a DNA adducts-inductor [20]. Those chromosome breaks may point to a clastogenic mode of action if unrepaired. Thus, it is important to refer to the basis of each method and procedure followed; since $\mathrm{MN}$ generated through clastogenic or aneugenic events, are irreversible and persistent, and time that approximates a 1.5-2 normal cell cycle of the cell line is crucial.

Finally, the mycotoxin mixture OTA + BEA in HepG2 cells showed an arrest in the G0/G1 and $S$ phases (Figure $3 \mathrm{C}$ ) correlated with the MN induction detected (Figure 4). Mixture tested resulted in a stable solution (see Section 4.3). The natural occurrence of both mycotoxins has been reported in many maize fields and maize-based products worldwide [9,40]. According to the literature, BEA is not an inducer of the deletion of a DNA excision repair system gene [38], while oppositely, OTA has been reported as a DNA adducts-inductor [20]; therefore, this could support our results. DNA strand breaks through a COMET assay have been detected using a different in vitro system (PK-15 cells and human leukocytes) and exposure time for this combination and at doses lower than those presented in here (BEA: 0.1 and $0.5 \mu \mathrm{M}$; OTA: 1 and $5 \mu \mathrm{M}$ ). Coinciding with our results, a positive genotoxic effect was obtained.

In conclusion, individual and combined BEA and OTA cytotoxicity in HepG2 cells was studied. In binary mixtures, synergism and additive effect prevailed. Both OTA and BEA and their combinations provoked disturbance in the cell cycle and affected MN induction, thus underlining the importance of studying real exposure scenarios of chronic exposure to these toxins.

\section{Materials and Methods}

\subsection{Reagents}

All reagents and cell culture components were standard laboratory grade from Sigma-Aldrich (St. Louis, MO, USA). The standard of OTA (MW: $403.815 \mathrm{~g} / \mathrm{mol}$ ) and BEA (MW: $783.95 \mathrm{~g} / \mathrm{mol}$ ) was purchased from Sigma-Aldrich (St. Louis, MO, USA). Methanol (MeOH) was obtained from Fisher Scientific (Madrid, Spain). For MTT assay, thiazolyl blue tetrazolium bromide (approx. 98\%; M2128-10G) was purchased from Sigma-Aldrich. A Milli-Q water purification system (Millipore, Bedford, MA, USA) permitted the obtainment of the deionized water ( $<18 \mathrm{M} \Omega \mathrm{cm}$ resistivity). Stock solutions of mycotoxins were prepared in $\mathrm{MeOH}$ (OTA and BEA) and maintained at $-20^{\circ} \mathrm{C}$ in the dark. The final concentration of $\mathrm{MeOH}$ in the medium was $\leq 1 \%(v / v)$ as per established for performing this in vitro assays.

\subsection{Cell Culture}

Growth of HepG2 cells (ATCC HB-8065) was possible using Dulbecco's Modified Eagle's Medium (DMEM, Sigma-Aldrich) supplemented with antibiotic-free 10\% newborn calf serum (NCS; Invitrogen, Christchurch, New Zealand), $100 \mathrm{U} / \mathrm{mL}$ penicillin, and $100 \mathrm{mg} / \mathrm{mL}$ streptomycin (Sigma-Aldrich). Cells 
were used between passages 12 and 19. The cells were trypsinized (Trypsin-EDTA, Sigma-Aldrich) and resuspended in complete medium in a 1:3 split ratio to perform the sub-cultivation. The procedure was repeated once or twice a week according to the monolayer confluence in flasks with filter screw caps (TPP, Trasadingen, Switzerland) at $37^{\circ} \mathrm{C}$ in a humidified atmosphere and $5 \% \mathrm{CO}_{2}$.

\subsection{Mycotoxin Exposure}

In this study, concentration of mycotoxins and exposure time were two important factors to consider. Twenty-four, 48, and $72 \mathrm{~h}$ were the exposure times assayed in HepG2 cells for BEA and OTA either individually and combined. The situation of $72 \mathrm{~h}$ was considered due to the accumulation process possibly occurring because of the physicochemical properties of these compounds. Individual treatment was assayed at a concentration range of 0 to $25 \mu \mathrm{M}$ for BEA (1:3 dilution), and at a range of 0 to $100 \mu \mathrm{M}$ for OTA (1:2 dilution). For combination mixtures, individual treatment data were crucial for selecting starting concentration. Nevertheless, parallel assays of individual and combinations were performed for exact evaluation of combinatory effects. Concentration for combinations of both mycotoxins at a dilution ratio 1:10 (BEA + OTA) was from 3.3 to $27.5 \mu \mathrm{M}$, including four dilutions of each mycotoxin combination for $\operatorname{BEA}(0.3,0.6,1.25$, and $2.5 \mu \mathrm{M})$ and OTA $(3.1,6.2,12.5$, and $25 \mu \mathrm{M})$.

\subsection{In Vitro Cytotoxicity}

The protocol published by Ruiz et al. [41], with slight modification, was followed to evaluate the cytotoxicity. It describes the MTT assay which consists of measuring the viability of cells by determining the reduction of the yellow, soluble tetrazolium salt only in cells that are metabolically active via a mitochondrial reaction to an insoluble, purple formazan crystal. The concentration of cells per well was $2 \times 10^{4}$ cells/well for culture plates of 96-wells. Cells adhered to the plates after 18-24 h, which was the elapsed time before proceeding with mycotoxin additions. Section 4.3 details the dilutions and combinations of mycotoxins tested for BEA and OTA. Fresh supplemented medium was used for preparing serial dilutions in the designed plate, while controls were prepared with culture medium with $<1 \%$ methanol. After passing 24,48 or $72 \mathrm{~h}$, the medium containing the mycotoxin was removed and $200 \mu \mathrm{L}$ of fresh medium containing $50 \mu \mathrm{L}$ of MTT solution was added ( $5 \mathrm{mg} / \mathrm{mL}$; MTT powder dissolved in phosphate buffered saline). Plates were kept for $4 \mathrm{~h}$ at $37^{\circ} \mathrm{C}$ in darkness and afterwards the MTT was removed and $200 \mu \mathrm{L}$ of DMSO and $25 \mu \mathrm{L}$ of Soerensen's solution (composition: glycine $0.4 \mu \mathrm{M}+0.1 \mu \mathrm{M} \mathrm{NaCl}, \mathrm{pH} 10.5$ ) was added to each well. Plates were brought to read at $570 \mathrm{~nm}$ with the ELISA plate reader Multiskan EX (Thermo Scientific, Waltham, MA, USA). Replicates consisted of each mycotoxin combination plus a control tested in three independent experiments. Mean inhibition concentration $\left(\mathrm{IC}_{50}\right.$ ) values were calculated from full dose-response curves using the four parameter logistic equation with the SigmaPlot program. Three independent experiments were performed with eight replicates each.

\subsection{Experimental Design and Combination Index}

The isobologram analysis (Chou-Talalay model) was used to determine the type of interaction (synergism or antagonism effect) that occurs when mycotoxins studied were in combination. Chou-Talalay's model allows characterizing the interactions induced by combinations of mycotoxins, but no mechanisms associated can be elucidated. Combination effects are possible to analyze by the median-effect/combination index (CI)-isobologram equation by Chou [42] and Chou and Talalay [7]. The model involves plotting the dose-effect curves for each mycotoxin and its combinations in multiple diluted concentrations. There are several parameters included in the equation as $D m$ (the median-effect dose), $f a$ (fraction affected by concentration), and $m$ (coefficient signifying the shape of the dose-effect relationship) [7]. Therefore, both the potency $(\mathrm{Dm})$ and shape $(m)$ parameters are crucial for the evaluation. 
The term combination index (CI) is included in Chou and Talalay's [42] method. According to the CI synergism, additive, and antagonism are, respectively, correlated as follows: $\mathrm{CI}<1,=1$, and $>1$. CalcuSyn software version 2.1. (Biosoft, Cambridge, UK, 1996-2007) was used to study the types of interactions assessed by isobologram analysis. It was decided to report $\mathrm{CI}_{25}, \mathrm{CI}_{50}, \mathrm{CI}_{75}$, and $\mathrm{CI}_{90}$ doses to produce toxicity at $25 \%, 50 \%, 75 \%$, and $90 \%$, respectively.

\subsection{Cell Cycle Analysis by Flow Cytometry}

Vindelov's PI staining solution previously described [43] was used. PI is a DNA intercalating agent that only stains stoichiometrically the DNA of cells in the late phases of cell death, when the integrity of both cellular and nuclear membranes is lost. Cell proliferation and cell cycle distribution was performed using BD FACSCanto ${ }^{\mathrm{TM}}$ Flow Cytometer (Beckton-Dickinson, Italy) with FACSDiva software version 6.1.3 (BD Biosciences, San José, CA, USA, 2007).

For this assay, plates of 6 wells were used and the concentration of cells was $4.8 \times 10^{5}$. Cells were seeded for $24 \mathrm{~h}$ and exposed for $48 \mathrm{~h}$ to BEA at $0.31,0.62,1.25$, and $2.5 \mu \mathrm{M}$ for $48 \mathrm{~h}$; and OTA at $3.12,6.25$, 12.5 , and $25 \mu \mathrm{M}$ for individual treatment. For combinations, range doses went from 3.43 to $27.5 \mu \mathrm{M}$ including four dilutions of each combination. Then, cells were trypsinized and incubated at $37^{\circ} \mathrm{C}$ for $30 \mathrm{~min}$ with $860 \mu \mathrm{L}$ of fresh medium containing $29 \mathrm{ng} / \mathrm{mL}$ of Vindelov's PI staining solution. Cell cycle analysis was carried out as described by Minervini et al. [44], by rectangular fitting (CYLCHRED software, Beckton-Dickinson, Milan, Italy) using 1024 channels, which produced histograms with a single G0/G1 peak at channel 200 when DNA was diploid, an S-peak between channels 200 and 400 when DNA was replicating, a G2/M peak at channels 400 when DNA was tetraploid, and a Sub-G0 peak (debris peak), between 100 and 200 when DNA was hypodiploid or damaged. The reduced coefficient of variation (CV) obtained in this study was the result of the high resolution reached by proper alignment. The positive control used was cicloheximide (CLX) $(40 \mu \mathrm{g} / \mathrm{mL})$, known as synthesis of proteins inhibitor that leads to cellular quiescence and cell death by apoptosis. Three independent experiments were performed for OTA and BEA and at least 10,000 cells were analyzed for each sample.

\subsection{Genotoxic Evaluation by Micronucleus Detection through Flow Cytometry}

Litron In Vitro Microflow Kit (Litron Laboratories, Rochester, NY, USA) was used for the micronucleus assay on HepG2 cells exposed to mycotoxins by flow cytometry following the OECD TG487. Conditions set for this assay point that it must be carried out after exposure of cells to the toxic during a time that approximates a 1.5-2-times normal cell cycle. For HepG2 cells, this time was set to $48 \mathrm{~h}$; which doubled the time period necessary for this type of cell (2 normal cycles). Concentrations were maintained as per those detailed in Section 4.5 and were also used in the cell cycle assay. Previous reports [18,45-48] and manufacturer's instructions (Litron Laboratories, 2009) were followed, all according to the framework of the OECD Guideline [16].

Briefly, in 24-well plates, HepG2 cells $\left(2 \times 10^{6}\right.$ cells $\left./ \mathrm{mL}\right)$ were seeded and treated with BEA and OTA as detailed in Section 4.5 for $48 \mathrm{~h}$. The day of the experiment Nucleic Acid Dye A Solution was added to the cells, placed on ice, and exposed to light for $30 \mathrm{~min}$ for photoactivation of the EMA flurorochrome dye. Afterwards, cells were washed and lysed with the Litron Lysis kit solution and preserved from light for $60 \mathrm{~min}$. Afterwards, cells were gently resuspended and a lysis solution 2 containing Nucleic Acid Dye B (SYTOX flurorochrome) was added, incubated for $30 \mathrm{~min}$ at room temperature in the dark, and analyzed by flow cytometry. Gating cell population and analysis strategies were performed with the FACS Fortesa 7.1 software following the instructions and template provided with the in vitro microflow kit manual and as described by Bryce et al. [46,47]. The control cells received equal volume of the vehicle (cell culture medium). Etoposide was used as the positive control $[45,47,49]$. The percentage of micronucleus was determined after acquiring a total of 20,000 gated nuclei events per sample as indicated in OECD TG 487 for MN evaluation through flow cytometry. 


\subsection{Statistical Analysis}

Statistical analysis of data was carried out using the IBM SPSS Statistic version 24.0 (SPSS, Chicago, IL, USA, 2017) statistical software package. Data were expressed as the mean \pm SEM of four independent experiments. The statistical analysis of the results was performed by student's $t$-test for paired samples. Differences between groups were statistically analyzed using ANOVA followed by the Tukey HDS post-hoc test for multiple comparisons. $p \leq 0.05$ was considered statistically significant.

Author Contributions: Conceptualization: A.J.-G.; Methodology: A.J.-G.; Software: A.J.-G.; Validation: A.J.-G.; Formal analysis: A.J.-G.; Investigation: A.J.-G. and M.-J.R.; Resources: A.J.-G., C.J., J.T. and M.-J.R.; Data curation: A.J.-G.; Writing-Original Draft Preparation: A.J.-G. and C.J.; Writing-Review \& Editing: A.J.-G. and M.-J.R.; Visualization: A.J.-G.; Supervision: M.-J.R.; Project Administration: M.-J.R.; Funding Acquisition: M.-J.R., C.J. and A.J.-G.

Funding: This research was funded by Spanish Ministry of Economy and Competitiveness grant number AGL2016-77610-R.

Acknowledgments: This work has been funded by the Spanish Ministry of Economy and Competitiveness AGL2016-77610-R.

Conflicts of Interest: The authors declare no conflict of interest.

\section{References}

1. Juan-García, A.; Juan, C.; Manyes, L.; Ruiz, M.J. Binary and tertiary combination of alternariol, 3-acetyl-deoxynivalenol and 15-acetyl-deoxynivalenol on HepG2 cells: Toxic effects and evaluation of degradation products. Toxicol. In Vitro 2016, 34, 264-273. [CrossRef] [PubMed]

2. Juan-García, A.; Juan, C.; Tolosa, J.; Ruiz, M.J. Effects of deoxynivalenol, 3-acetyl-deoxynivalenol and 15-acetyl-deoxynivalenol on parameters associated with oxidative stress in HepG2 cells. Mycotoxin Res. 2019, 1-9. [CrossRef] [PubMed]

3. Ruiz, M.J.; Franzova, P.; Juan-García, A.; Font, G. Toxicological interactions between the mycotoxins beauvericin, deoxynivalenol and T-2 toxin in CHO-K1 cells in vitro. Toxicon 2011, 58, 315-326. [CrossRef] [PubMed]

4. Ruiz, M.J.; Macáková, P.; Juan-García, A.; Font, G. Cytotoxic effects of mycotoxin combinations in mammalian kidney cells. Food Chem. Toxicol. 2011, 49, 2718-2724. [CrossRef] [PubMed]

5. Ferrer, E.; Juan-García, A.; Font, G.; Ruiz, M.J. Reactive oxygen species induced by beauvericin, patulin and zearalenone in CHO-K1 cells. Toxicol. In Vitro 2009, 23, 1504-1509. [CrossRef] [PubMed]

6. Maranghi, F.; Tassinari, R.; Narcis, L.; Tait, S.; La Rocca, C.; Di Felice, G.; Butteroni, C.; Corinti, S.; Barletta, B.; Cordelli, E.; et al. In vivo toxicity and genotoxicity of beauvericin and enniatins. Combined approach to study in vivo toxicity and genotoxicity of mycotoxins beauvericin (BEA) and enniatin B (ENNB). EFSA Support. Publ. 2018, 15, 1406E. [CrossRef]

7. Chou, T.C.; Talalay, P. Quantitative analysis of dose-effect relationships: The combined effects of multiple drugs or enzyme inhibitors. Adv. Enzym. Regul. 1984, 22, 27-55. [CrossRef]

8. Chou, T.C.; Hayball, M.P. CalcuSyn for Windows: Multiple-drug Dose-effect Analyzer and Manual; Biosoft: Cambridge, UK, 1997.

9. Juan-García, A.; Juan, C.; König, B.; Ruiz, M.J. Cytotoxic effects and degradation products of three mycotoxins: Alternariol, 3-acetyl-deoxynivalenol and 15-acetyl-deoxynivalenol in liver hepatocellular carcinoma cells. Toxicol. Lett. 2015, 235, 8-16. [CrossRef]

10. Juan, C.; Berrada, H.; Mañes, J.; Oueslati, S. Multi-mycotoxin determination in barley and derived products from Tunisia and estimation of their dietary intake. Food Chem. Toxicol. 2017, 103, 148-156. [CrossRef]

11. Oueslati, S.; Berrada, H.; Mañes, J.; Juan, C. Presence of mycotoxins in Tunisian infant foods samples and subsequent risk assessment. Food Control 2017, 84, 362-369. [CrossRef]

12. Stanciu, O.; Juan, C.; Miere, D.; Loghin, F.; Mañes, J. Occurrence and co-occurrence of Fusarium mycotoxins in wheat grains and wheat flour from Romania. Food Control 2017, 73, 147-155. [CrossRef] 
13. Regulation (EC) No 1107/2009 of the European Parliament and of the Council of 21 October 2009 Concerning the Placing of Plant Protection Products on the Market and Repealing Council Directives 79/117/EEC and 91/414/EEC. Official Journal of the European Union. Available online: http://data.europa.eu/eli/reg/2009/ 1107/oj (accessed on 8 November 2018).

14. Commission Regulation (EC) No 429/2008 of 25 April 2008 on Detailed Rules for the Implementation of Regulation (EC) No 1831/2003 of the European Parliament and of the Council as Regards the Preparation and the Presentation of Applications and the Assessment and the Authorisation of Feed Additives. Available online: http://data.europa.eu/eli/reg/2008/429/oj (accessed on 8 November 2018).

15. Commission Regulation (EC) No 1881/2006 of 19 December 2006 Setting Maximum Levels for Certain Contaminants in Foodstuffs. Available online: https://eur-lex.europa.eu/LexUriServ/LexUriServ.do?uri=OJ: L:2006:364:0005:0024:EN:PDF (accessed on 8 November 2018).

16. OECD. Test No. 487: In Vitro Mammalian Cell Micronucleus Test. Series OECD Guidelines for the Testing of Chemicals, Section 4: Health Effects. Available online: https://read.oecd-ilibrary.org/environment/test-no-487in-vitro-mammalian-cell-micronucleus-test_9789264264861-en\#page1 (accessed on 8 November 2018).

17. Shi, J.; Bezabhie, R.; Szkudlinska, A. Further evaluation of a flow cytometric in vitro micronuclei assay in CHO-K1 cells: A reliable platform that detects micronuclei and discriminates apoptotic bodies. Mutagenesis 2010, 25, 33-40. [CrossRef] [PubMed]

18. Juan-García, A.; Taroncher, M.; Font, G.; Ruiz, M.J. Micronucleus induction and cell cycle alterations produced by deoxynivalenol and its acetylated derivatives in individual and combined exposure on HepG2 cells. Food Chem. Toxicol. 2018, 118, 719-725.

19. Ehrlich, V.; Darroudi, F.; Uhl, M.; Steinkellner, H.; Gann, M.; Majer, B.J.; Eisenbauer, M.; Knasmüller, S. Genotoxic effects of ochratoxin A in human-derived hepatoma (HepG2) cells. Food Chem. Toxicol. 2002, 40, 1085-1090. [CrossRef]

20. Costa, J.; Saraiva, N.; Guerreiro, P.; Louro, H.; Silva, M.J.; Miranda, J.P.; Castro, M.; Batinic-Haberle, I.; Fernandes, A.S.; Oliveira, N.G. Ochratoxin A-induced cytotoxicity, genotoxicity and reactive oxygen species in kidney cells: An integrative approach of complementary endpoints. Food Chem. Toxicol. 2016, 87, 65-76. [CrossRef] [PubMed]

21. Ali, R.; Mittelstaedt, R.A.; Shaddock, J.G.; Ding, W.; Bhalli, J.A.; Khan, Q.M.; Heflich, R.H. Comparative analysis of micronuclei and DNA damage induced by Ochratoxin A in two mammalian cell lines. Mutat. Res. 2011, 723, 58-64. [CrossRef] [PubMed]

22. Knasmüller, S.; Cavin, C.; Chakraborty, A.; Darroudi, F.; Majer, B.J.; Huber, W.W.; Ehrlich, V.A. Structurally related mycotoxins ochratoxin $A$, ochratoxin $B$, and citrinin differ in their genotoxic activities and in their mode of action in human-derived liver (HepG2) cells: Implications for risk assessment. Nutr. Cancer 2004, 50, 190-197.

23. González-Arias, C.A.; Trinidad-Benitez, A.B.; Sordo, M.; Robledo-Marenco, L.; Medina-Día, I.M.; Barrón-Vivanco, B.S.; Marín, S.; Sanchis, V.; Ramos, A.J.; Rojas-García, A.E. Low doses of ochratoxin A induce micronucleus formation and delay DNA repair in human lymphocytes. Food Chem. Toxicol. 2014, 74, 249-254.

24. Dönmez-Altuntas, H.; Dumlupinar, G.; Imamoglu, N.; Hamurcu, Z.; Cem Liman, B. Effects of the mycotoxin citrinin on micronucleus formation in a cytokinesis-block genotoxicity assay in cultured human lymphocytes. J. Appl. Toxicol. 2006, 27, 337-341. [CrossRef]

25. Alves, I.; Oliveira, N.G.; Laires, A.; Rodrigues, A.S.; Rueff, J. Induction of micronuclei and chromosomal aberrations by the mycotoxin patulin in mammalian cells: Role of ascorbic acid as a modulator of patulin clastogenicity. Mutagenesis 2000, 15, 229-234. [CrossRef]

26. Celik, M.; Aksoy, H.; Yılmaz, S. Evaluation of beauvericin genotoxicity with the chromosomal aberrations, sister-chromatid exchanges and micronucleus assays. Ecotoxicol. Environ. Saf. 2010, 73, 1553-1557. [CrossRef] [PubMed]

27. Corcuera, L.A.; Vettorazzi, A.; Arbillaga, L.; Pérez, N.; Gil, A.G.; Azqueta, A.; González-Peñas, E.; García-Jalón, J.A.; López de Cerain, A. Genotoxicity of Aflatoxin B1 and Ochratoxin A after simultaneous application of the in vivo micronucleus and comet assay. Food Chem. Toxicol. 2015, 76, 116-224. [CrossRef] [PubMed] 
28. Klaric, M.S.; Darabos, D.; Rozgaj, R.; Kasuba, V.; Pepeljnjak, S. Beauvericin and ochratoxin A genotoxicity evaluated using the alkaline comet assay: Single and combined genotoxic action. Arch. Toxicol. 2010, 84, 641-650. [CrossRef] [PubMed]

29. Commission Recommendation of 17 August 2006 on the Prevention and Reduction of Fusarium Toxins in Cereals and Cereal Products. Available online: http://data.europa.eu/eli/reco/2006/583/oj (accessed on 8 November 2018).

30. Schaaf, G.J.; Nijmeijer, S.M.; Maas, R.F.; Roestenberg, P.; de Groene, E.M.; Fink-Gremmels, J. The role of oxidative stress in the ochratoxin A-mediated toxicity in proximal tubular cells. BBA-Mol. Basis Dis. 2002, 1588, 149-158. [CrossRef]

31. Giromini, C.; Rebucci, R.; Fusi, E.; Rossi, L.; Saccone, F.; Baldi, A. Cytotoxicity, apoptosis, DNA damage and methylation in mammary and kidney epithelial cell lines exposed to ochratoxin A. Cell Biol. Toxicol. 2016, 32, 249-258. [CrossRef] [PubMed]

32. Ramyaa, P.; Krishnasamy, R.; Padma, V.V. Quercetin modulates OTA-induced oxidative stress and redox signaling in HepG2 cells-Up regulation of Nrf2 expression and downregulation of NF-jB and COX-2. BBA-Gen. Subj. 2014, 1840, 681-692. [CrossRef] [PubMed]

33. Jow, G.M.; Chou, C.J.; Chen, B.F.; Tsai, J.H. Beauvericin induces cytotoxic effects in human acute lymphoblastic leukemia cells through cytochrome c release, caspase 3 activation: The causative role of calcium. Cancer Lett. 2004, 216, 165-173. [CrossRef]

34. Prosperini, A.; Meca, G.; Font, G.; Ruiz, M.J. Study of the cytotoxic activity of beauvericin and fusaproliferin and bioavailability in vitro on Caco-2 cells. Food Chem. Toxicol. 2012, 50, 2356-2361. [CrossRef]

35. Prosperini, A.; Juan-García, A.; Font, G.; Ruiz, M.J. Reactive oxygen species involment in apoptosis and mitochondrial damage in Caco-2 cells induced by enniatins A, A1, B and B1. Toxicol. Lett. 2013, 222, 36-44. [CrossRef]

36. Zouaoui, N.; Mallebrera, B.; Berrada, H.; Abid-Essefi, S.; Bacha, H.; Ruiz, M.J. Cytotoxic effects induced by patulin, sterigmatocystin and beauvericin on CHO-K1 cells. Food Chem. Toxicol. 2016, 89, 92-103. [CrossRef]

37. Klaric, M.S.; Papeljnjak, S.; Domijan, A.M.; Petrik, J. Lipid peroxidation and glutathione levels in porcine kidney PK15 cells after individual and combined treatment with fumonisin B1, beauvericin and ochratoxin a. Basic Clin. Pharmacol. Toxicol. 2006, 100, 157-164. [CrossRef] [PubMed]

38. Fotso, J.; Smith, J.S. Evaluation of beauvericin toxicity with the bacterial bioluminescence assay and the AMES mutagenicity bioassay. J. Food Sci. 2003, 68, 1938-1941. [CrossRef]

39. Follman, W.; Behn, C.; Degen, G.H. Toxicity of the mycotoxin citrinin and its metabolite dihydrocitrinone and of mixtures of citrinin and ochratoxin A in vitro. Arch. Toxicol. 2014, 88, 1097-1107. [CrossRef] [PubMed]

40. Domijan, A.; Peraica, M.; Cvjetkovic, B.; Turcin, S.; Jurjevic, Z.; Ivic, D. Mould contamination and co-occurrence of mycotoxins in maize grain in Croatia. Acta Pharm. 2005, 55, 349-356. [PubMed]

41. Ruiz, M.J.; Festila, L.E.; Fernández, M. Comparison of basal cytotoxicity of seven carbamates in CHO-K1 cells. Toxicol. Environ. Chem. 2006, 88, 345-354. [CrossRef]

42. Chou, T.C. Theoretical basis, experimental design, and computerized simulation of synergism and antagonism in drug combination studies. Pharmacol. Rev. 2006, 58, 621-681. [CrossRef] [PubMed]

43. Juan-García, A.; Manyes, L.; Ruiz, M.J.; Font, G. Involvement of enniatins-induced cytotoxicity in human HepG2 cells. Toxicol. Lett. 2013, 218, 166-173.

44. Minervini, F.; Fornelli, F.; Flynn, K.M. Toxicity and apoptosis induced by the mycotoxins nivalenol, deoxynivalenol and fumonisin B-1 in a human erythroleukemia cell line. Toxicol. In Vitro 2004, 18, 21-28. [CrossRef]

45. Bazin, E.; Mourot, A.; Humpage, A.R.; Fessard, V. Genotoxicity of a freshwater cyanotoxin, cylindrospermopsin, in two human cell lines: Caco-2 and HepaRG. Environ. Mol. Mutagen. 2010, 51, 251-259. [CrossRef]

46. Bryce, S.M.; Bemis, J.C.; Avlasevich, S.L.; Dertinger, S.D. In vitromicronucleus assay scored by flow cytometry provides a comprehensive evaluation of cytogenetic damage and cytotoxicity. Mutat. Res. 2007, 630, 78-91. [CrossRef]

47. Bryce, S.M.; Avlasevich, S.L.; Bemis, J.C.; Lukamowicz, M.; Elhajouji, A.; Van Goethem, F.; De Boeck, M.; Beerens, D.; Aerts, H.; Van Gompel, J.; et al. Interlaboratory evaluation of a flow cytometric high content in vitro micronucleus assay. Mutat. Res. 2008, 650, 181-195. [CrossRef] [PubMed] 
48. Bryce, S.M.; Shi, J.; Nicolette, J.; Diehl, S.P.; Avlasevich, S.; Raja, S.; Bemis, J.C.; Dertinger, S.D. High content flocytometric micronucleus scoring method is applicable to attachment cells lines. Environ. Mol. Mutagen. 2010, 51, 260-266.

49. Sahu, S.C.; O'Donnel, M.W.; Wiesenfeld, P.L. Comparative hepatotoxicity of deoxynivalenol in rat, mouse and human liver cells in culture. J. Appl. Toxicol. 2010, 30, 566-573. [CrossRef] [PubMed] 